\title{
THE IMPORTANCE OF PROFESSIONAL INVOLVEIMENT IN AVOCATIONAL ORGANIZATIONS - CASE HISTORY, THE DRY DREDGERS OF CINCINNATI, OHIO
}

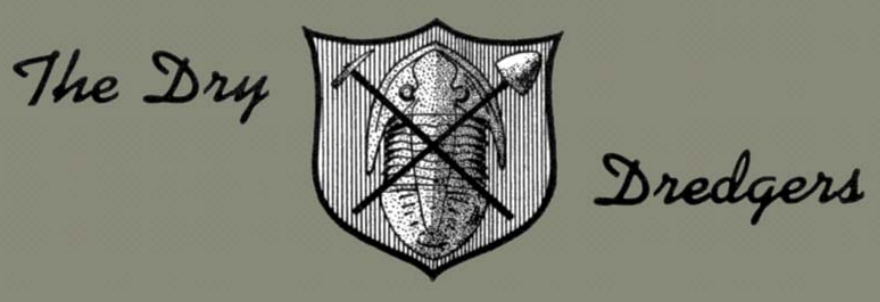

Jack W Kallmeyer

President

Dry Dredgers

Cincinnati, Ohio

\section{DRY DREDGERS \\ AN ASSOCIATION OF AMATEUR GEOLOGISTS \\ AND FOSSIL COLLECTORS}

75th Anniversary 


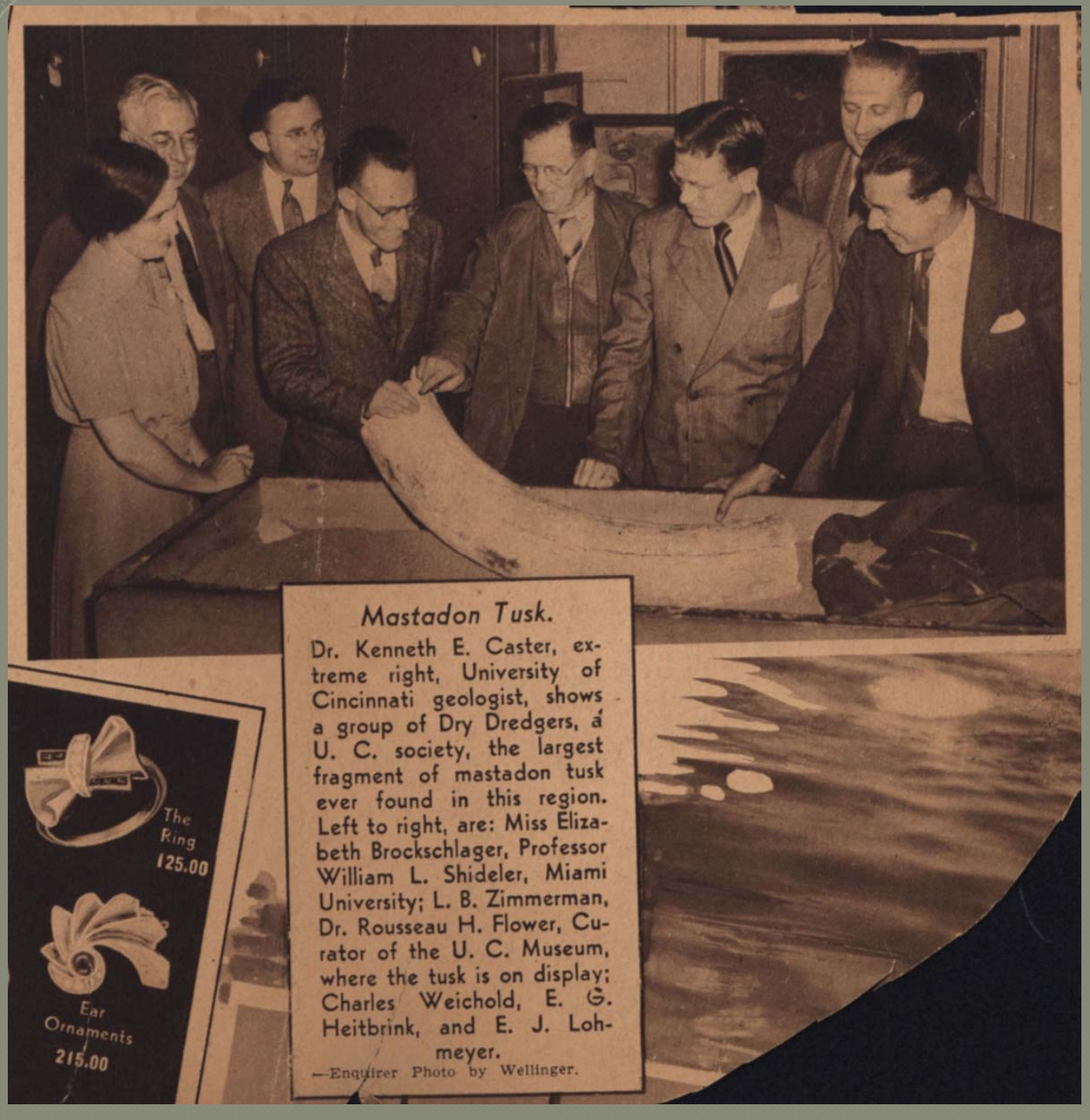

The Early Days - 1943
"Did you see the new starfish on display in the Museum? One superb specimen which shows certain details of the pore arrangement new to science, was found in Flat Fork Creek, Warren County, Ohio. Mrs. Erwin G. Heitbrink, discoverer, donated it to the Museum. This is a perfect example of unselfish cooperation; one which we hope we may all be fortunate enough to follow" - The Dredger, November, 1943

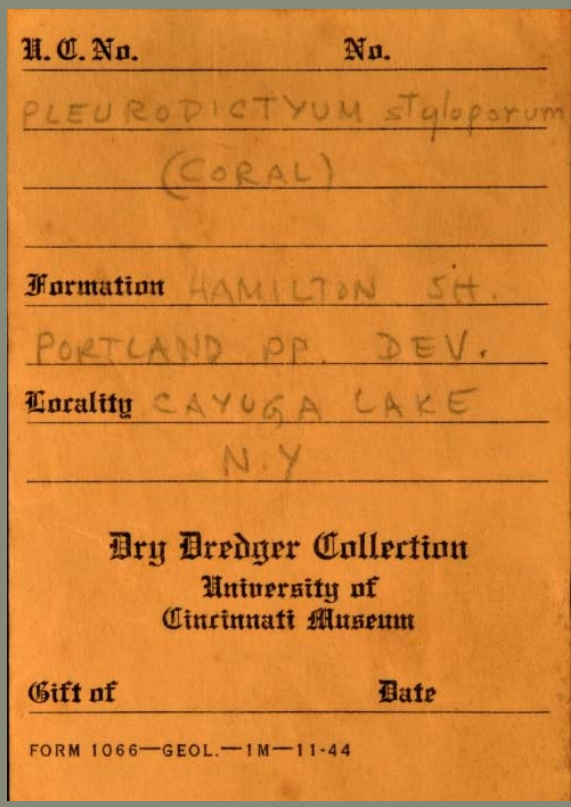




\section{Rousseau Flower - Member and Early Proponent of the Dry Dredgers}

"There has recently come Into existence an organization of amateur geologists in Cincinnati known as the Dry Dredgers. So many of my friends have contributed material, that I can mention only a few..." 1946

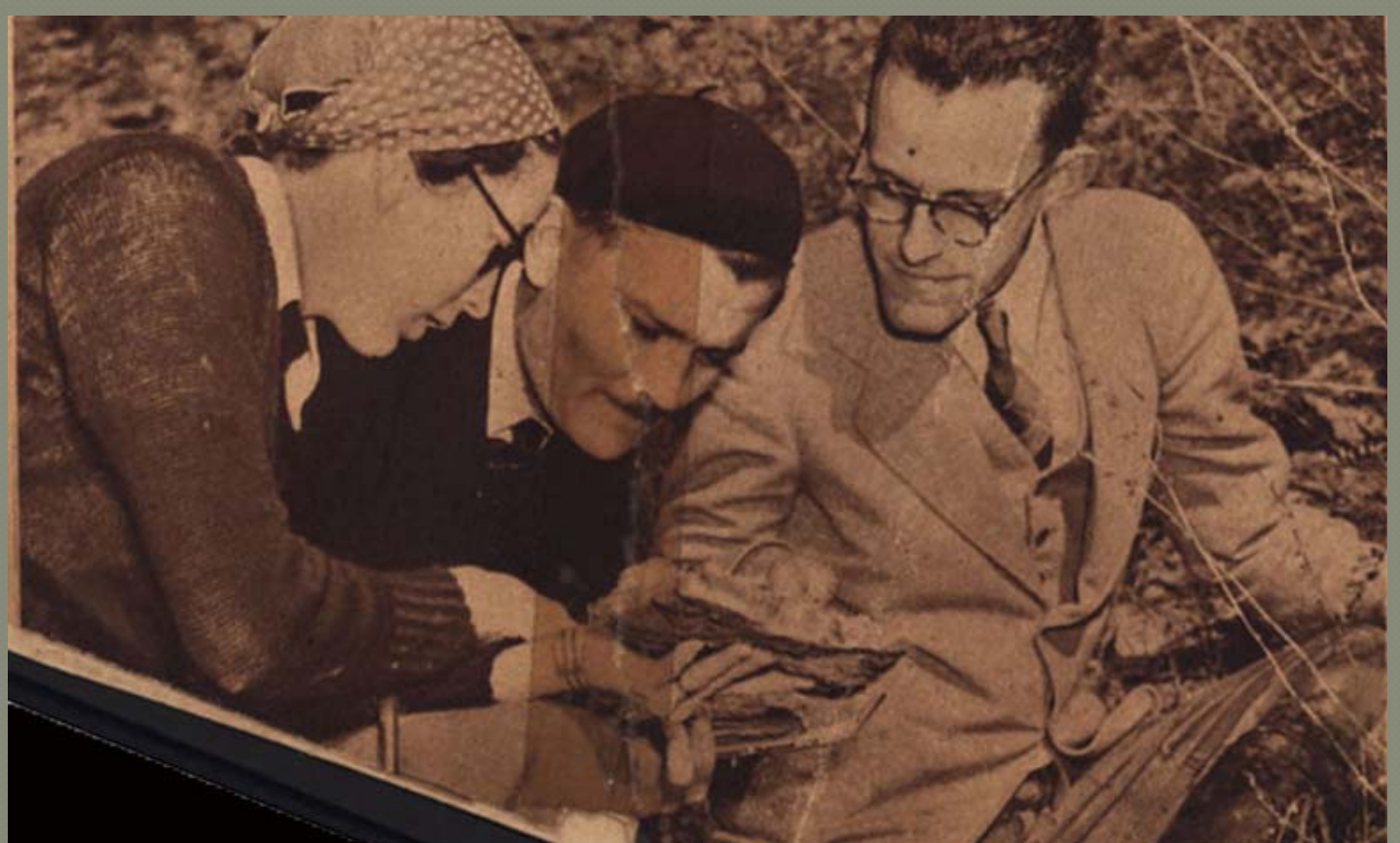

E. Dalvé
J. A. Dalvé
R. Flower
BULLETINS

OF

AMERICAN PALEONTOLOGY

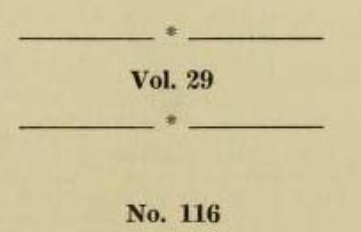

ORDOVICLAN CEPHALOPODS OF THF CINCINNATI REGION
Part I

By

Rousseau H. Flower New York State Museum
Formerly University of Cinciunat

\section{March 2I, 1946}


Dry Dredger Charles Cox discovers a nearly complete Eurypterid in the Cincinnatian around 1950. Megalograptus was the first Eurypterid to be documented from this area. The specimen was published in 1964 by Caster and Waering in Paleontographica Americana, Vol 4.

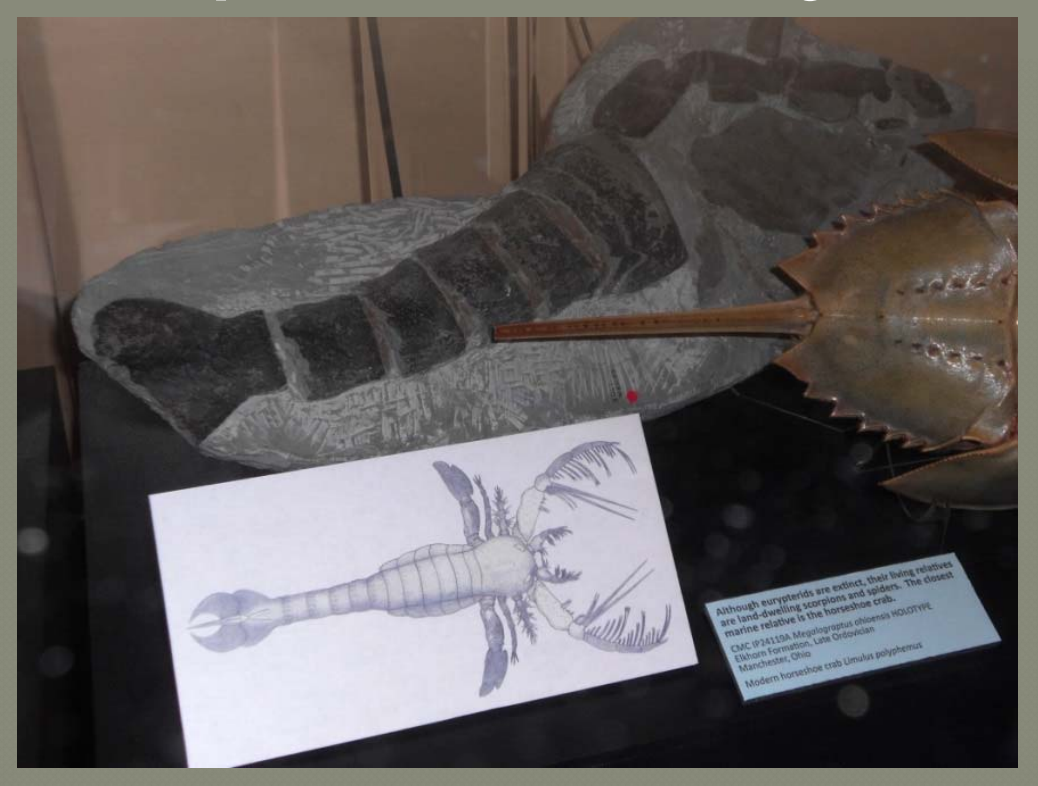

Dry Dredger and future professional paleontologist John Pope discovers a new Stylophoran from the Cincinnatian around 1950 - 1951. Caster describes it in 1952 and names it Enoploura popei

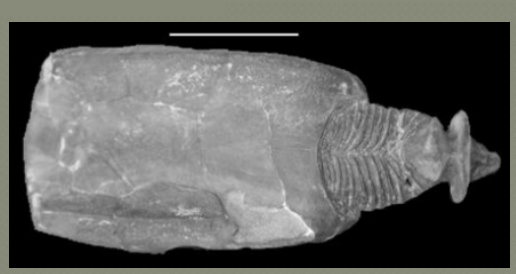

CMCIP 25993 Enoploura popei

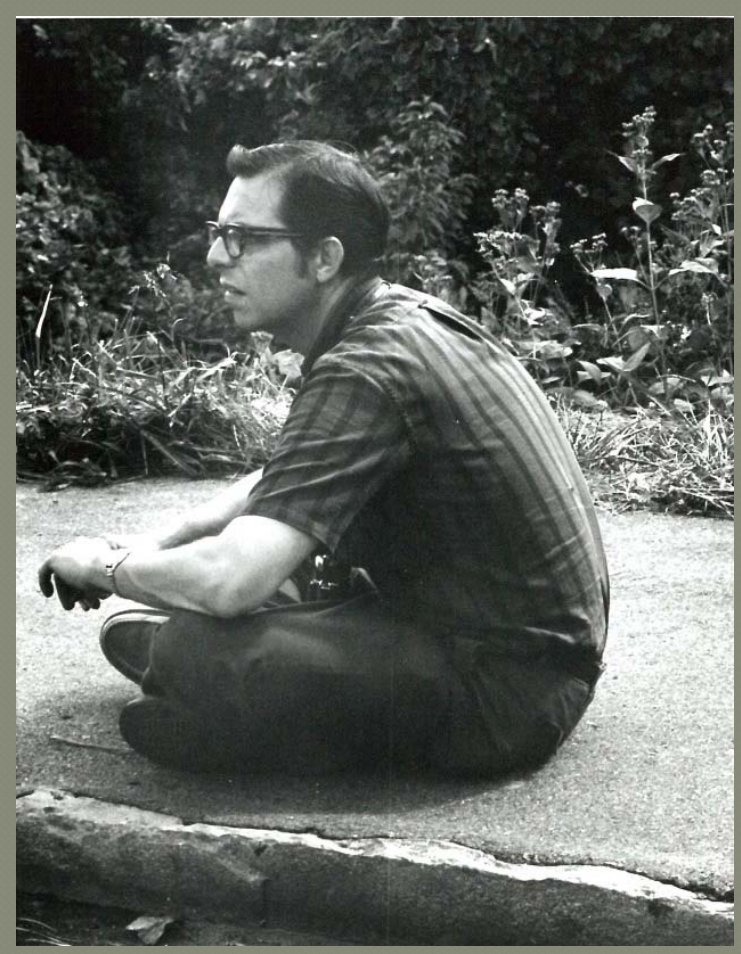


Professor Caster with the Dry

Dredgers in 1977

Always Teaching

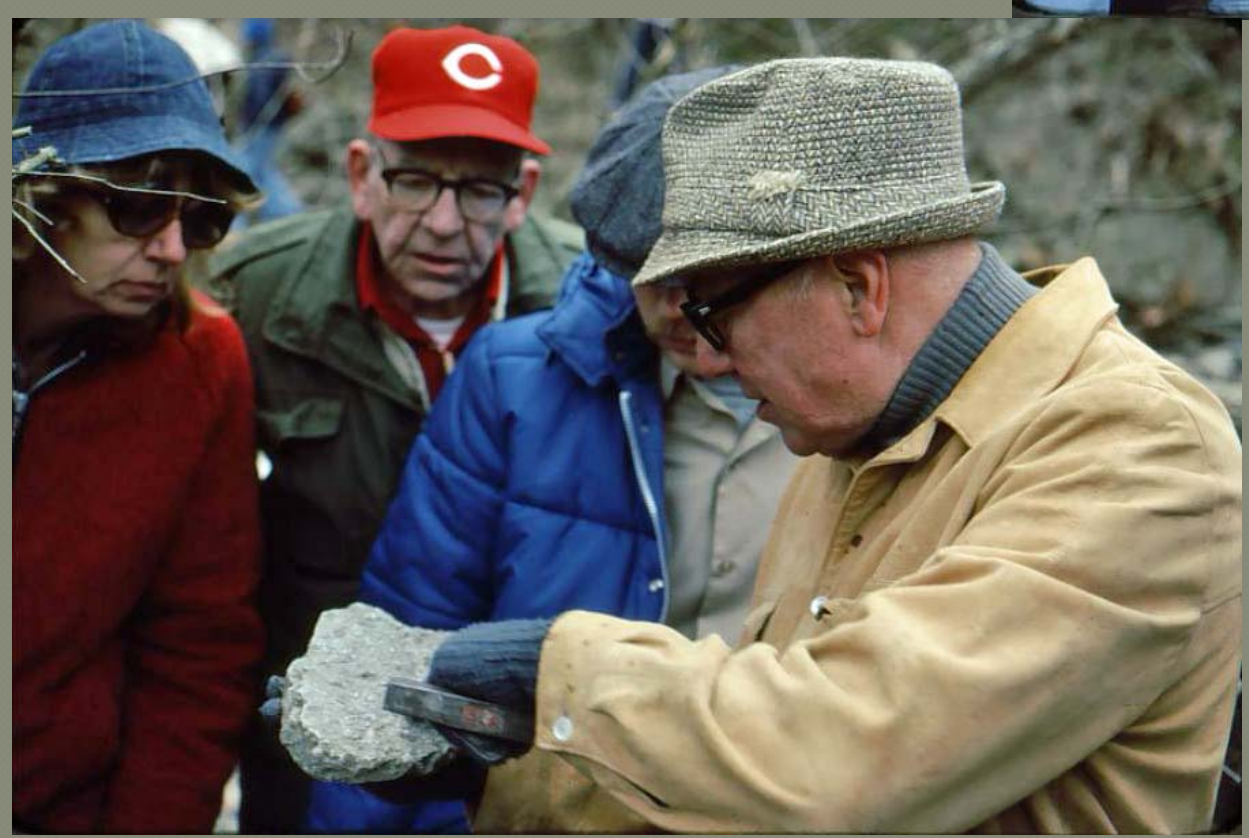




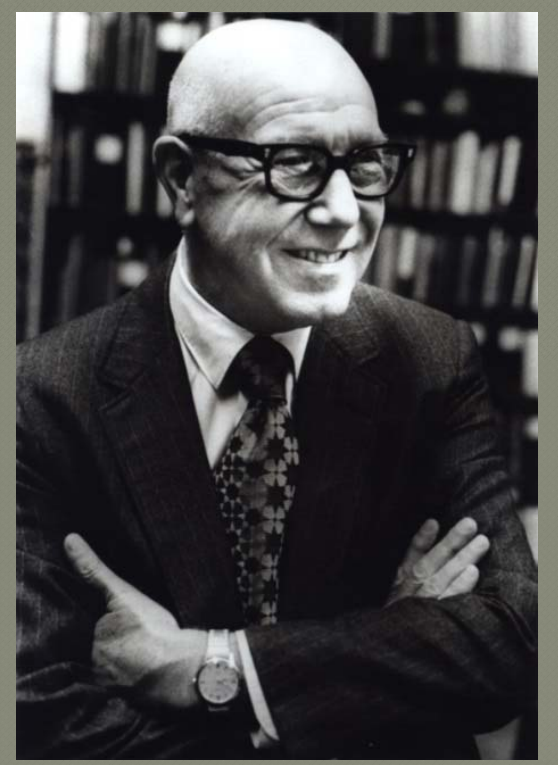

1985 - "There has not been a paper written by myself or my students at U.C. and related to local fossils in the last 45 years in which Dry Dredgers contributions of materials have not had a significant role, sometimes a dominant one." Ken Caster

1985 - "I feel that one of Ken's most important public services was the organization in his early days of the Cincinnati Dry Dredgers. This organization not only provides a center for the exchange of information, professional advice, and instruction for amateurs, but also has greatly enhanced the collections of the U.C. Geology Museum and the Cincinnati Museum of Natural History through members' generous donations. Many of the important discoveries in this region have been made by members of the Dry Dredgers." John Pope

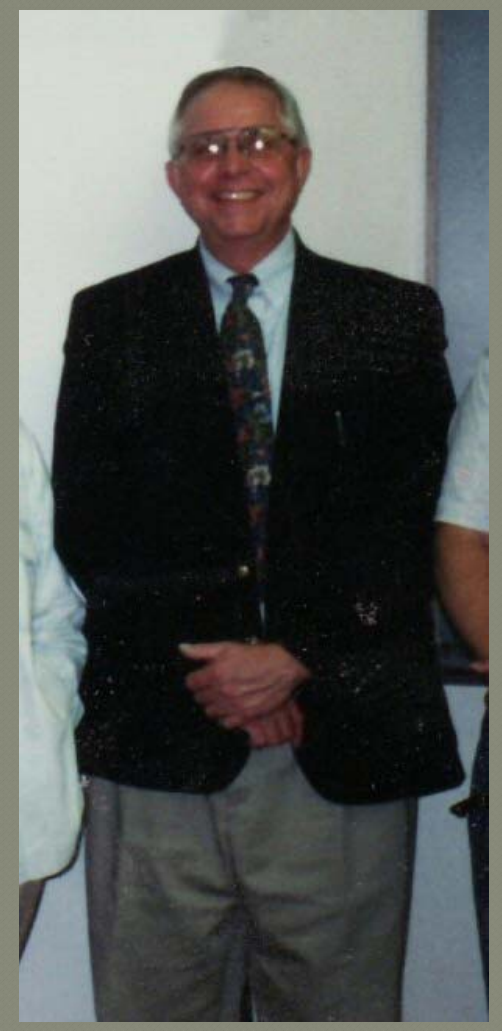




\section{Bill White $-2^{\text {nd }}$ Strimple Award Winner 1985}

Bill White discovers an exceptional edrioasteroid pavement and turns it over to then doctoral student Bruce Bell. Bill assisted in the excavations as well. This and other Dry Dredgers discovered pavements proved invaluable to Bell's work.
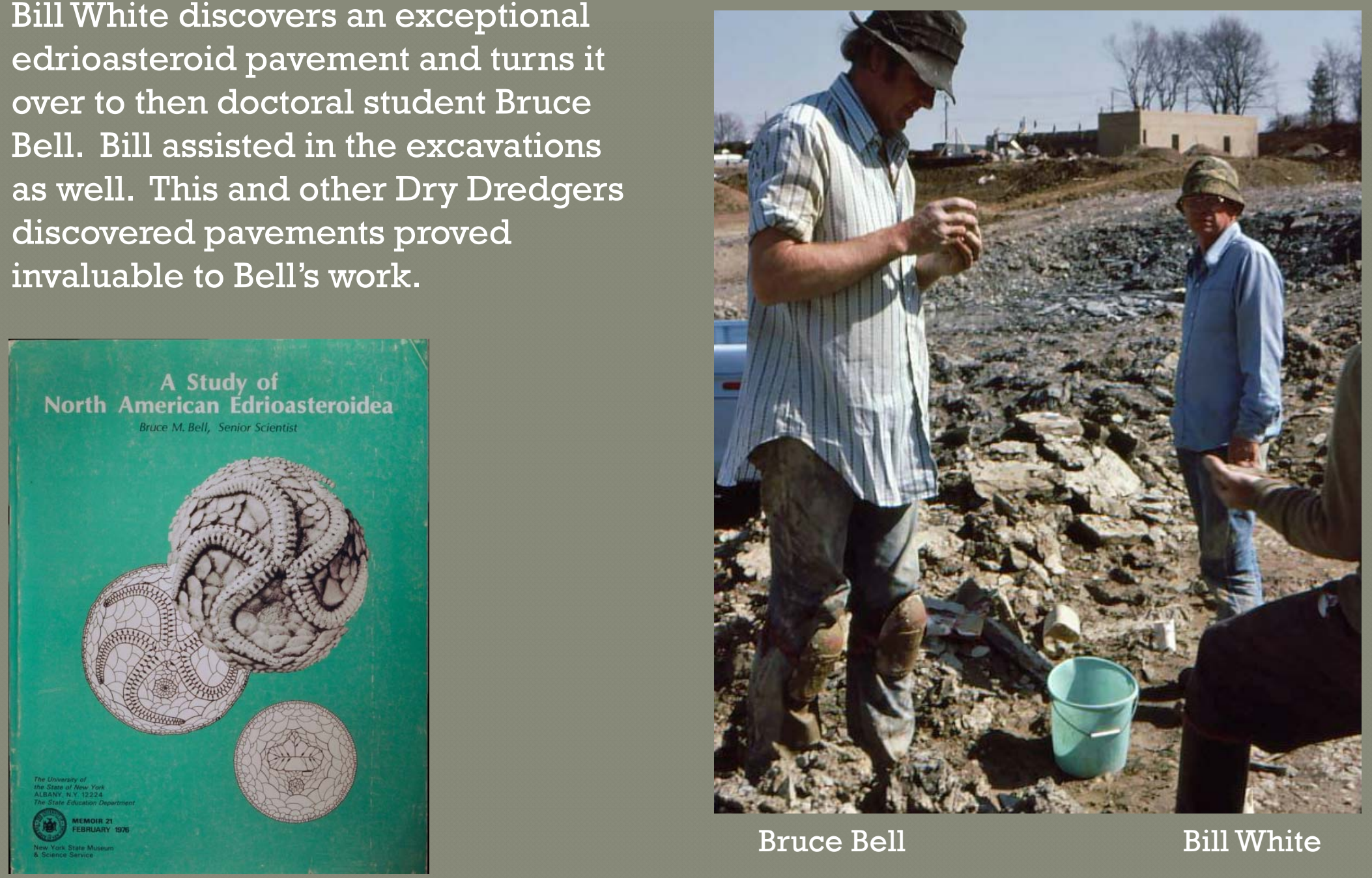


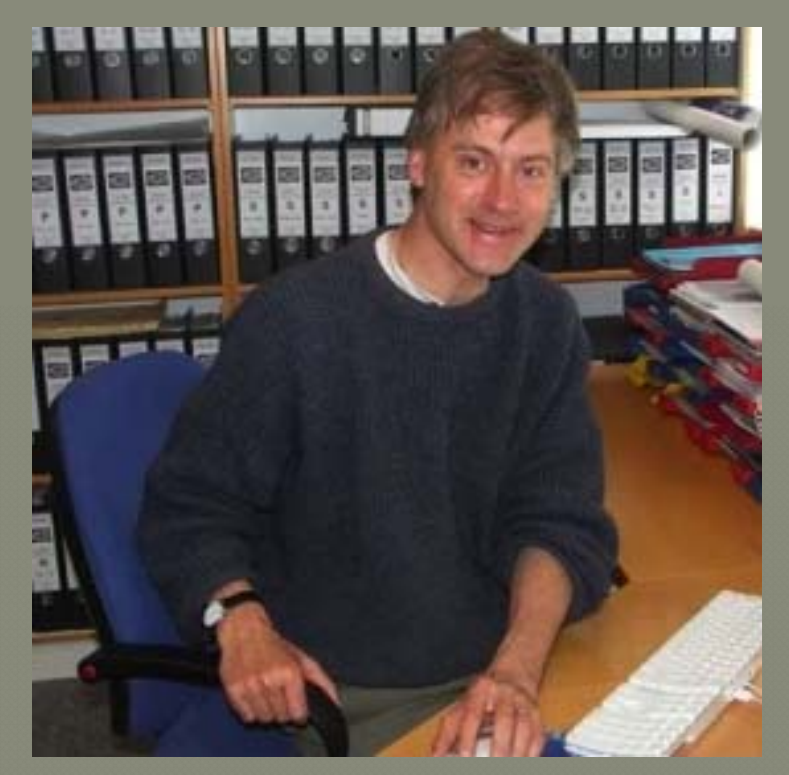

1996 - Dr. Nigel Hughes commented on the Dry Dredgers: "To call some of its members 'amateurs' is misleading - I use the term 'nonprofessional professionals' for those who diligently record the data on their collections, publish their investigations in leading journals, and deposit their specimens in the public trust." - GSA Today, Vol 6, No. 11.

\section{First Fossil Fest - 1996}

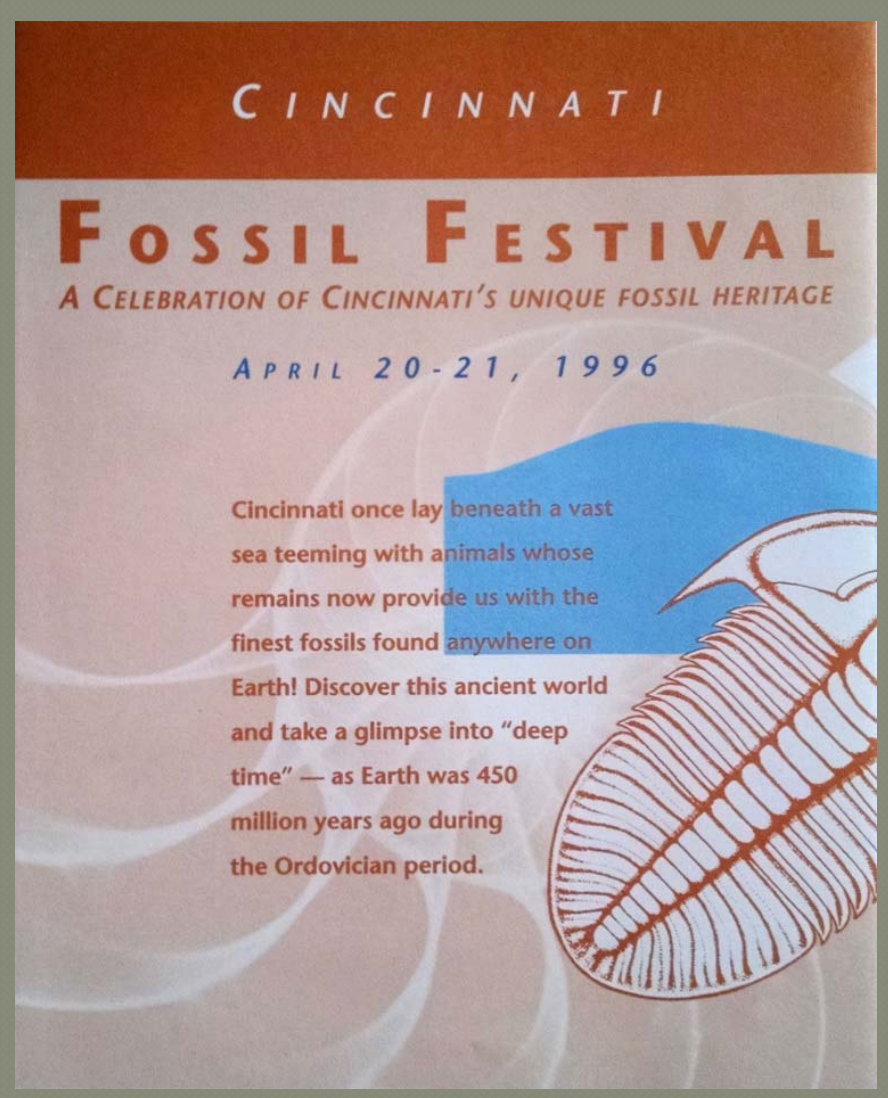




\section{Amateur Research Ramps up in the 1990's}

Dry Dredgers continue donations of specimens and assisting in field work but something changed. Dredgers become more involved in the research and begin appearing as authors and co-authors.

- 55 Peer Reviewed Papers

- 15 Theses

- 9 Books

- 22 Abstracts \& Posters

- 17 Other Publications 


\section{Steve Felton - Strimple Award Winner in 2001 and Winner of the PRI Katherine Palmer Award in 1996}

"The Amateur Scientists Who Might Cure Cancer-From Their Basements

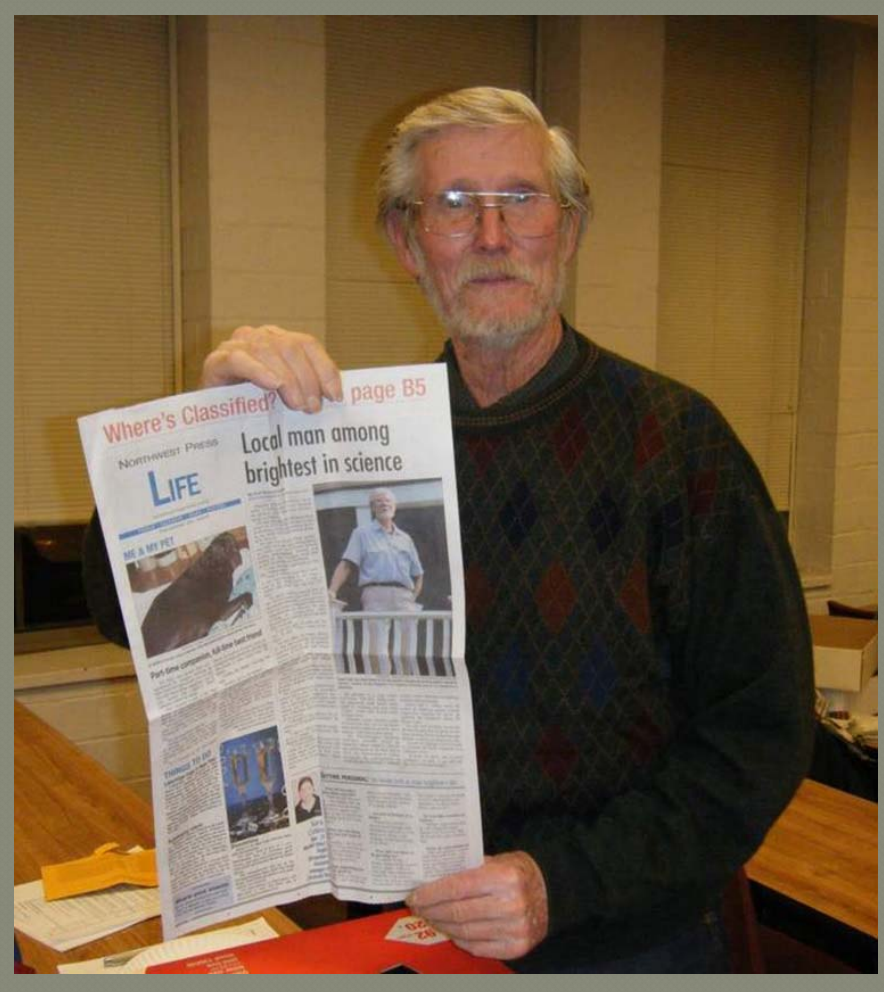
No Ph.D.? No university lab? No federal funding? No problem." - Discover Magazine December, 2008

Long known as our local expert on Cincinnatian Formations and Cyclonema gastropods, Cornulitids and trace fossils among other fauna

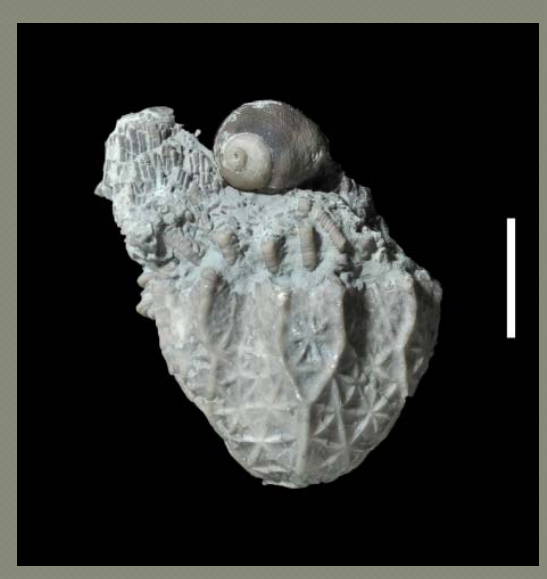




\section{Don Bissett provides access}

to his property for a graduate student studying trilobites

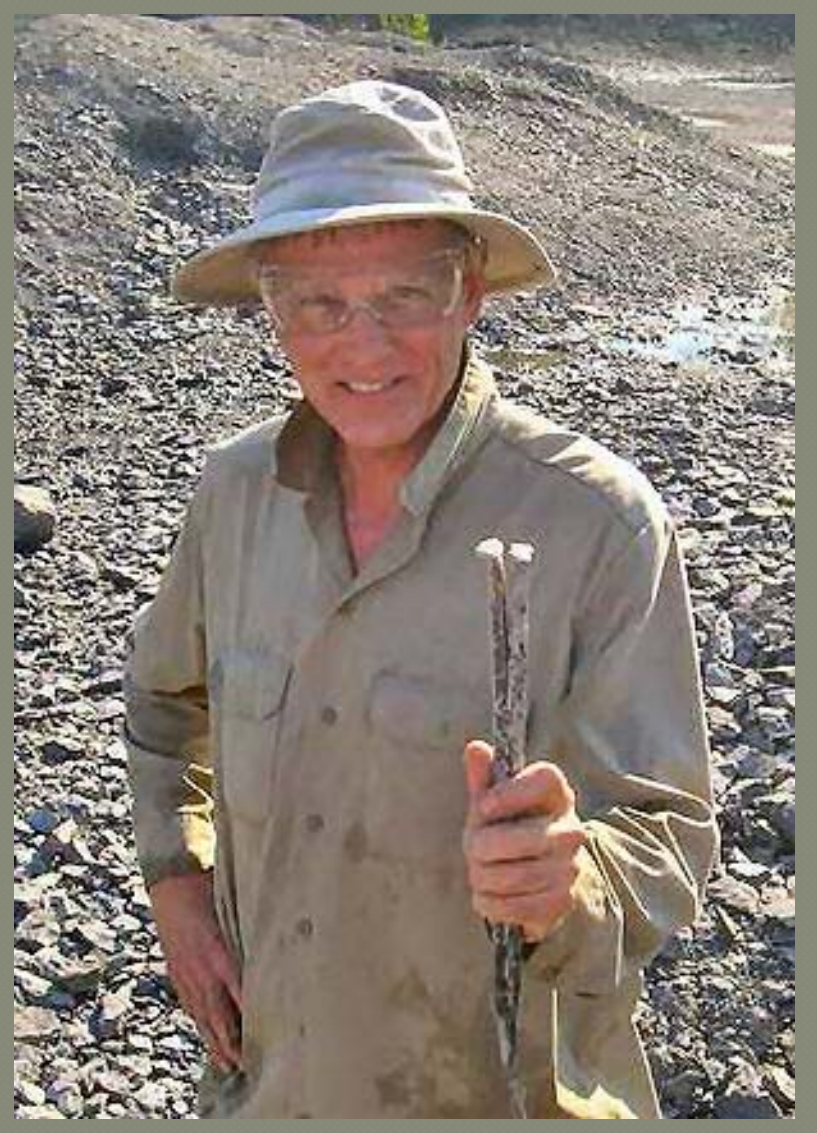

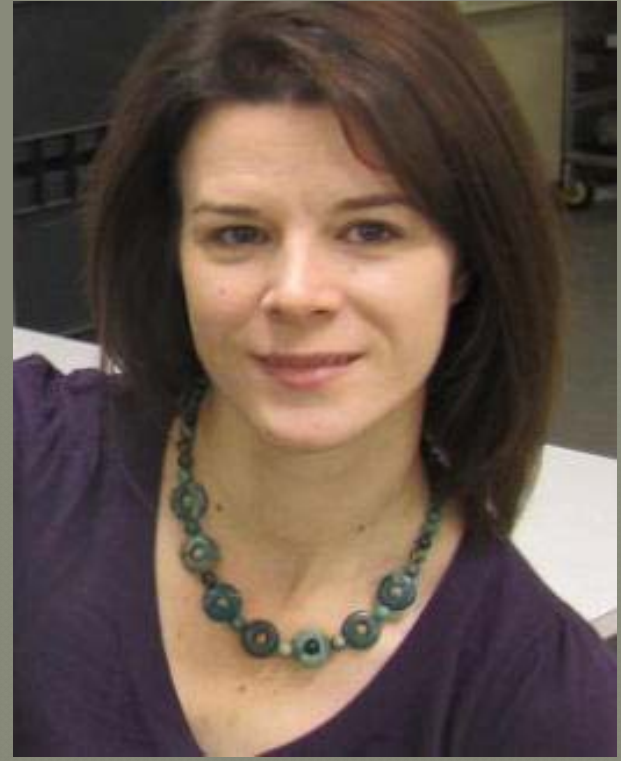

Brenda Hunda

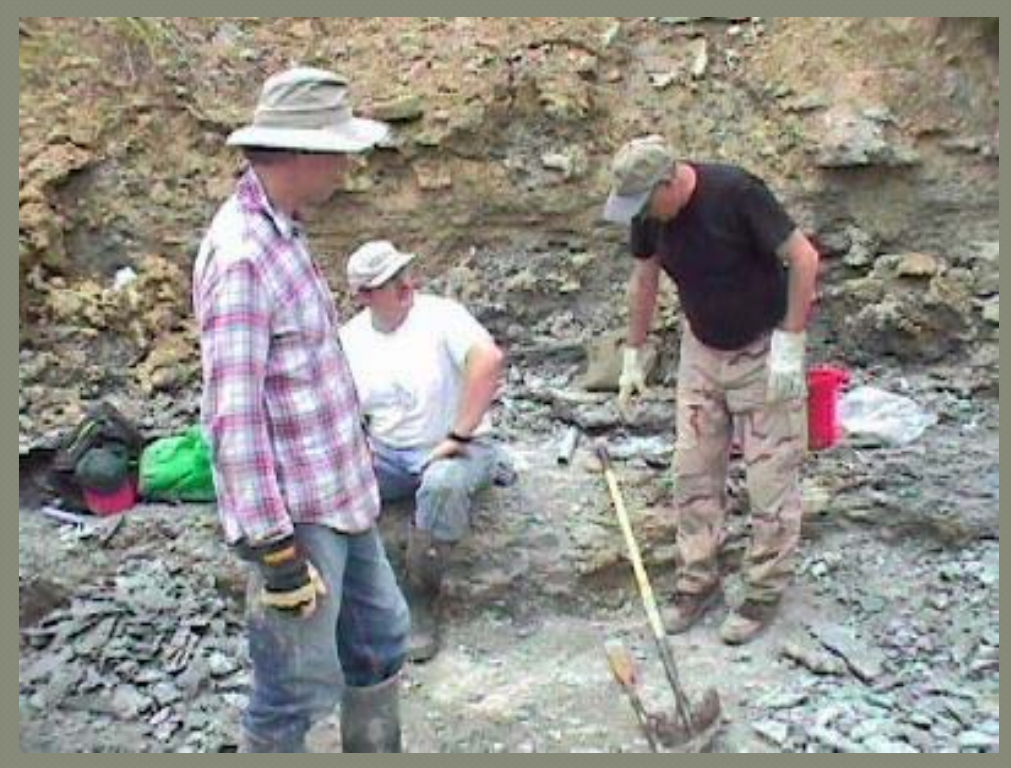

The famous Mt Orab trilobite farm 


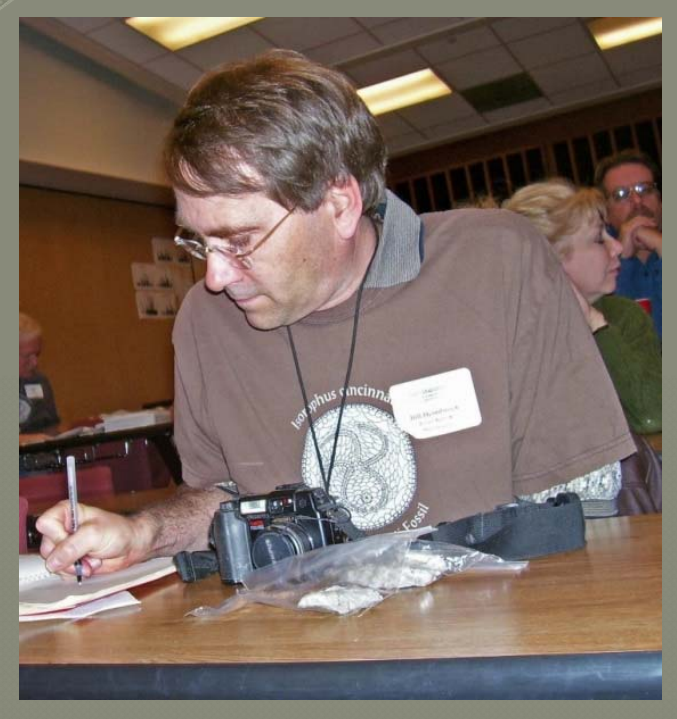

Bill Heimbrock assisted Michael Vendrasco in study of the earliest evidence of nacre in the fossil record
Bill also worked with Ben Dattilo and Rebecca Freeman to solve the riddle of tiny phosphatic steinkerns in the Cincinnatian
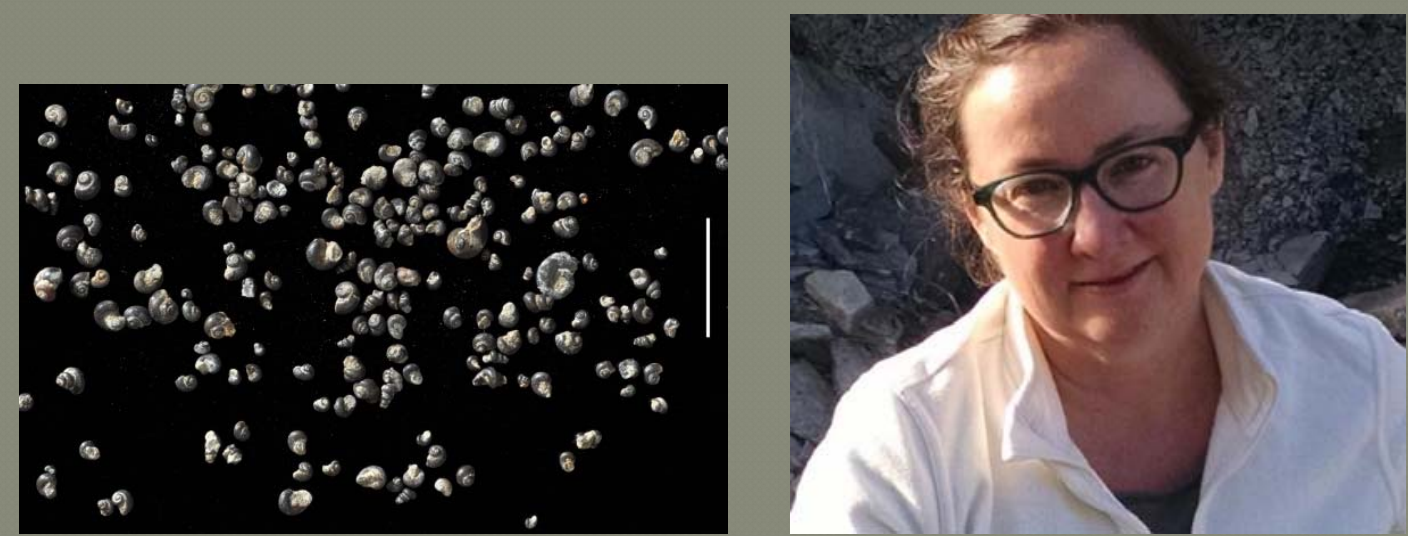
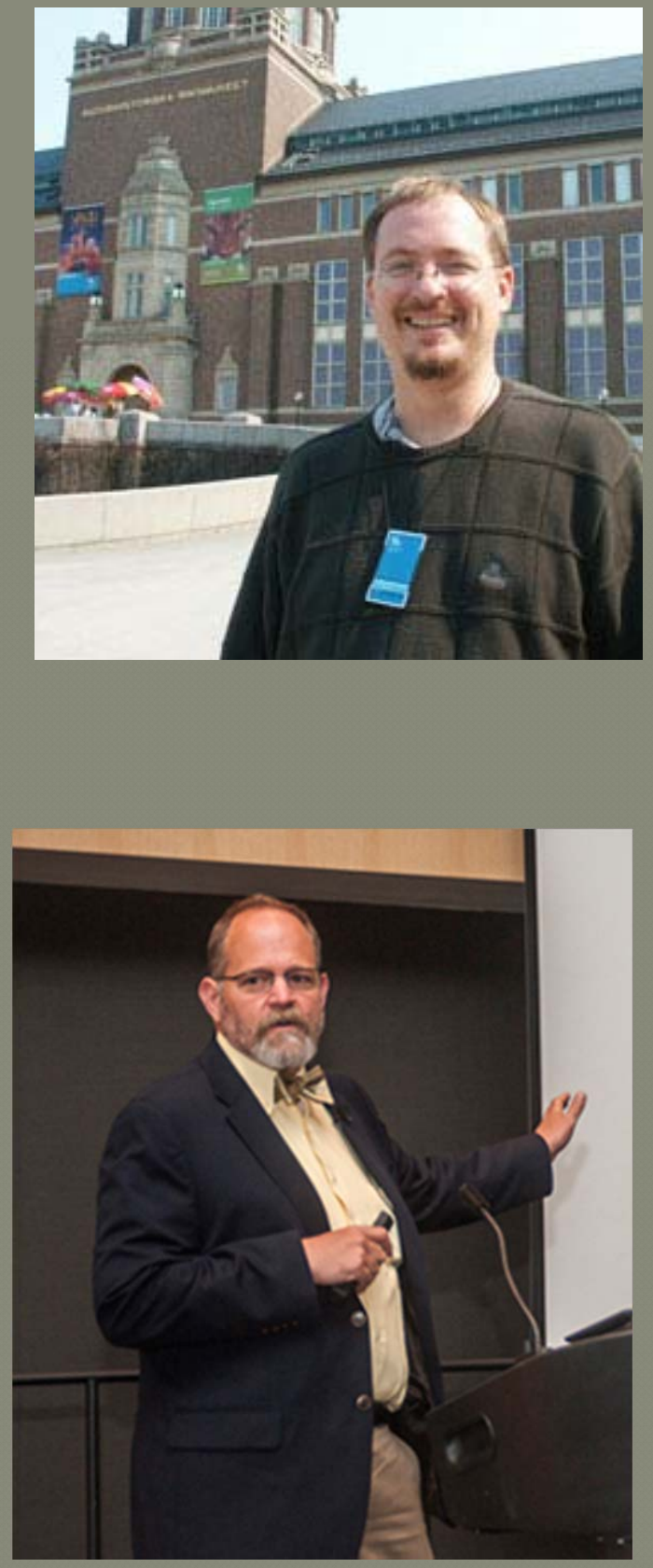


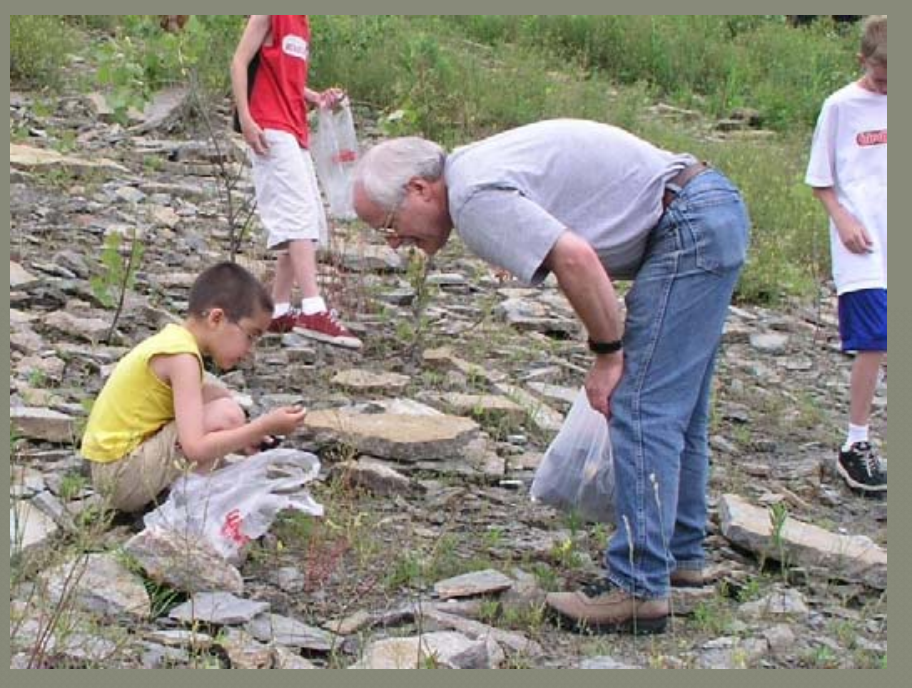

Tom Bantel and Don Bissett have

collaborated with James Thomka, Carl

Brett, Stig Bergstrom and other

Professionals for Ordovician/Silurian research at an Indiana quarry.
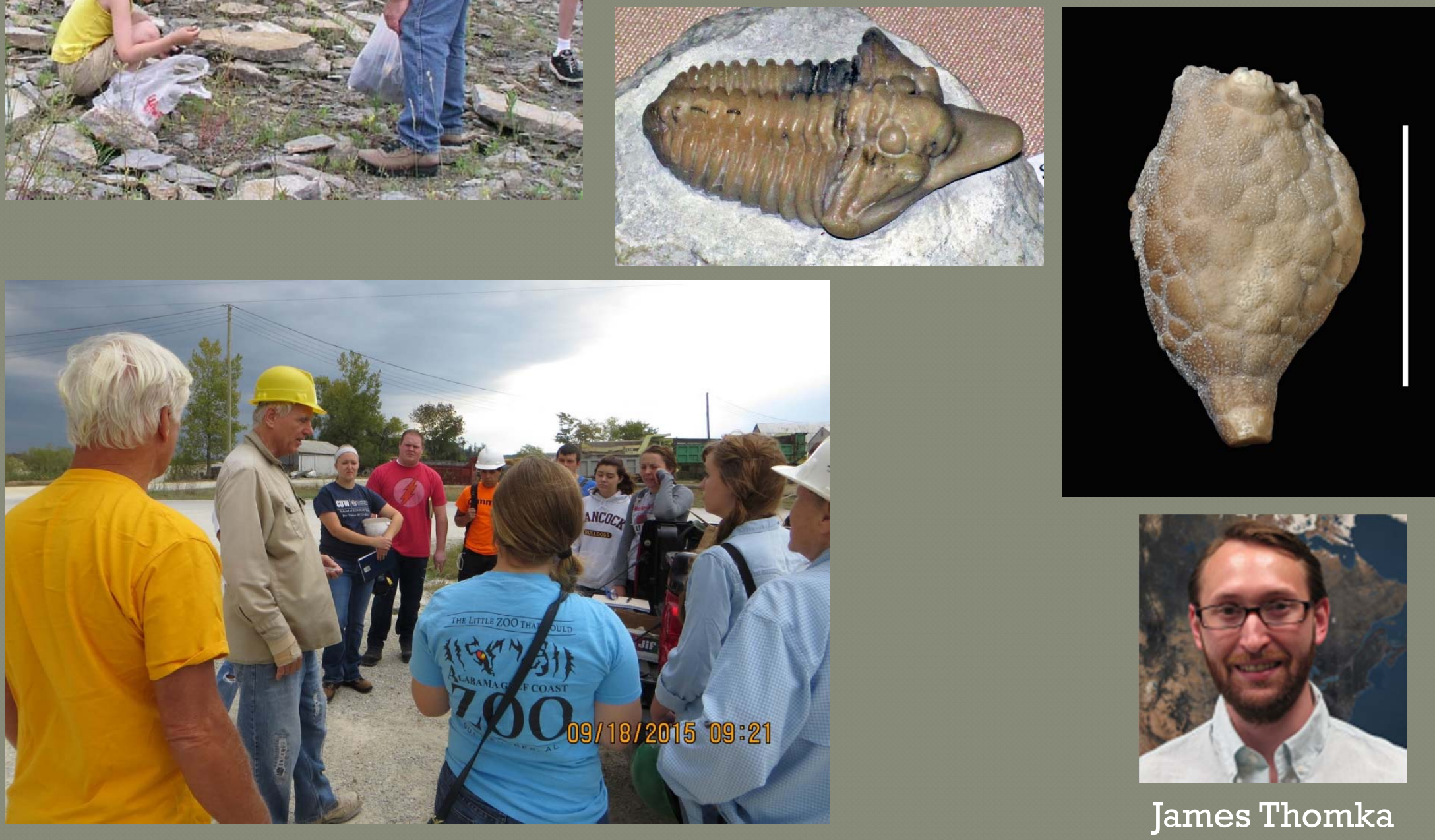

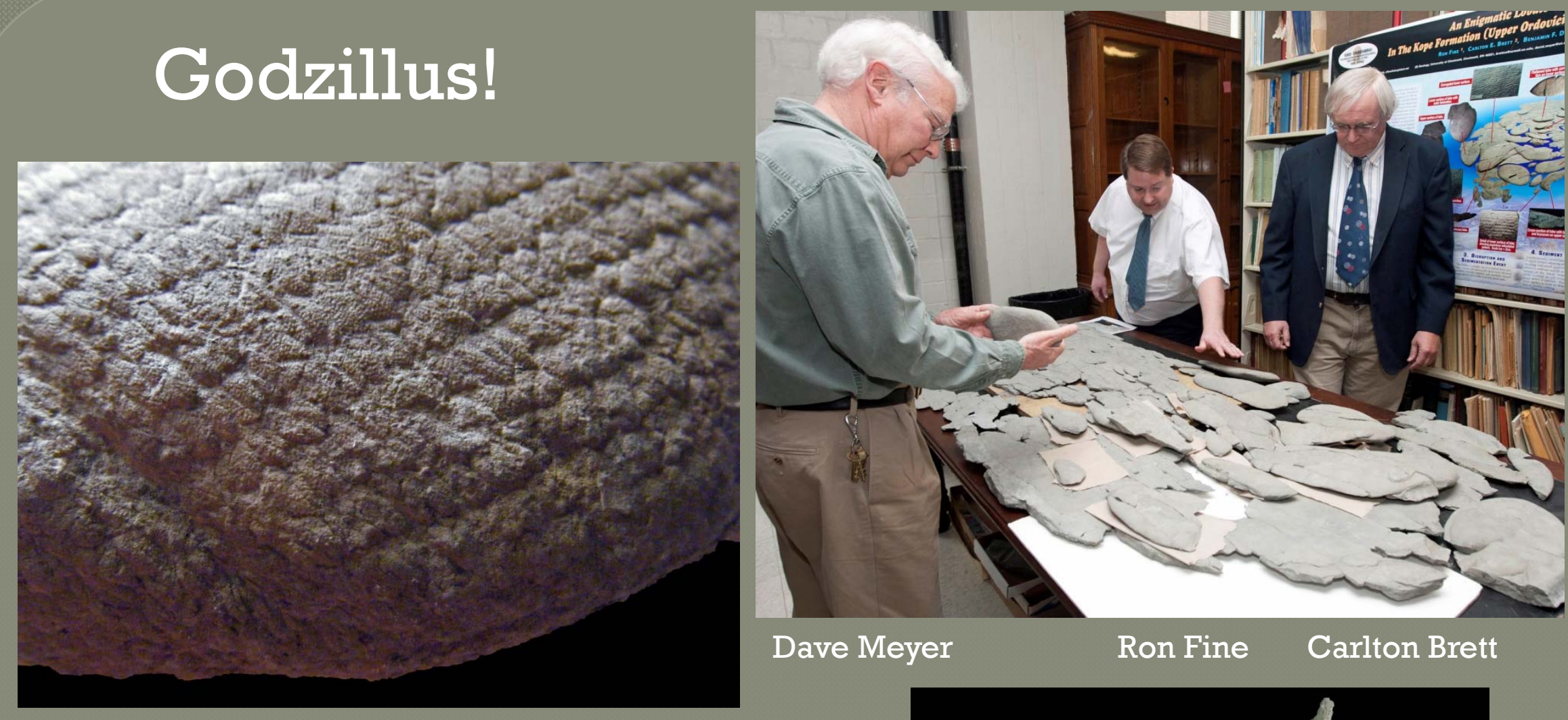

Dave Meyer

Ron Fine Carlton Brett
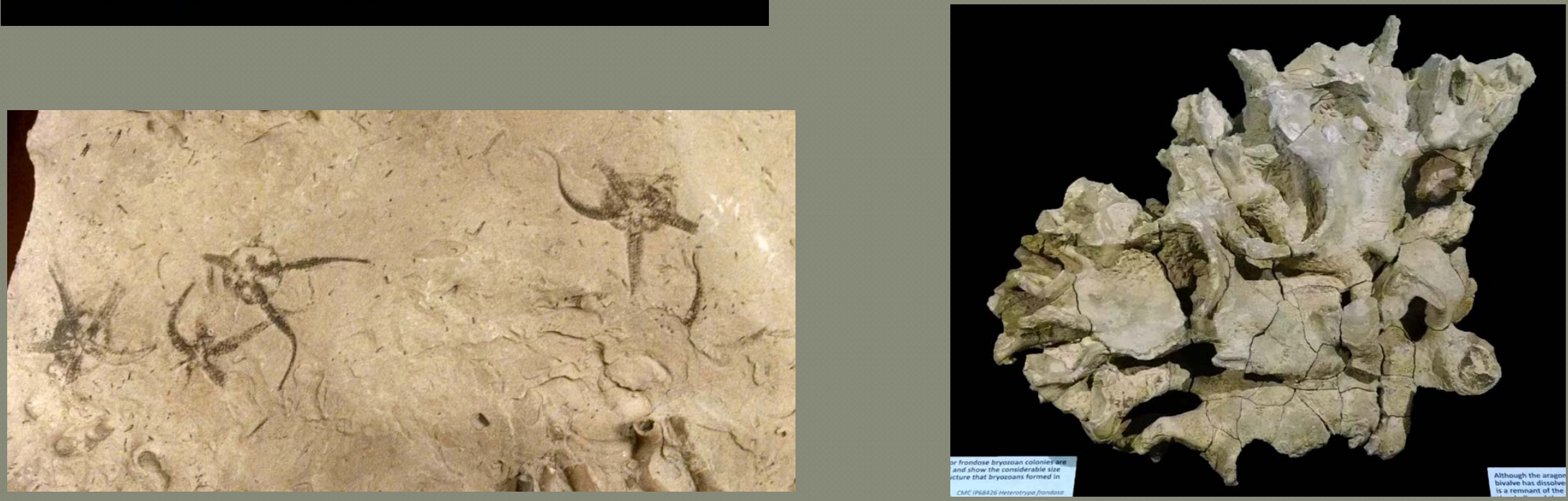


\section{Dan Cooper Donates Crinoid Assemblage}
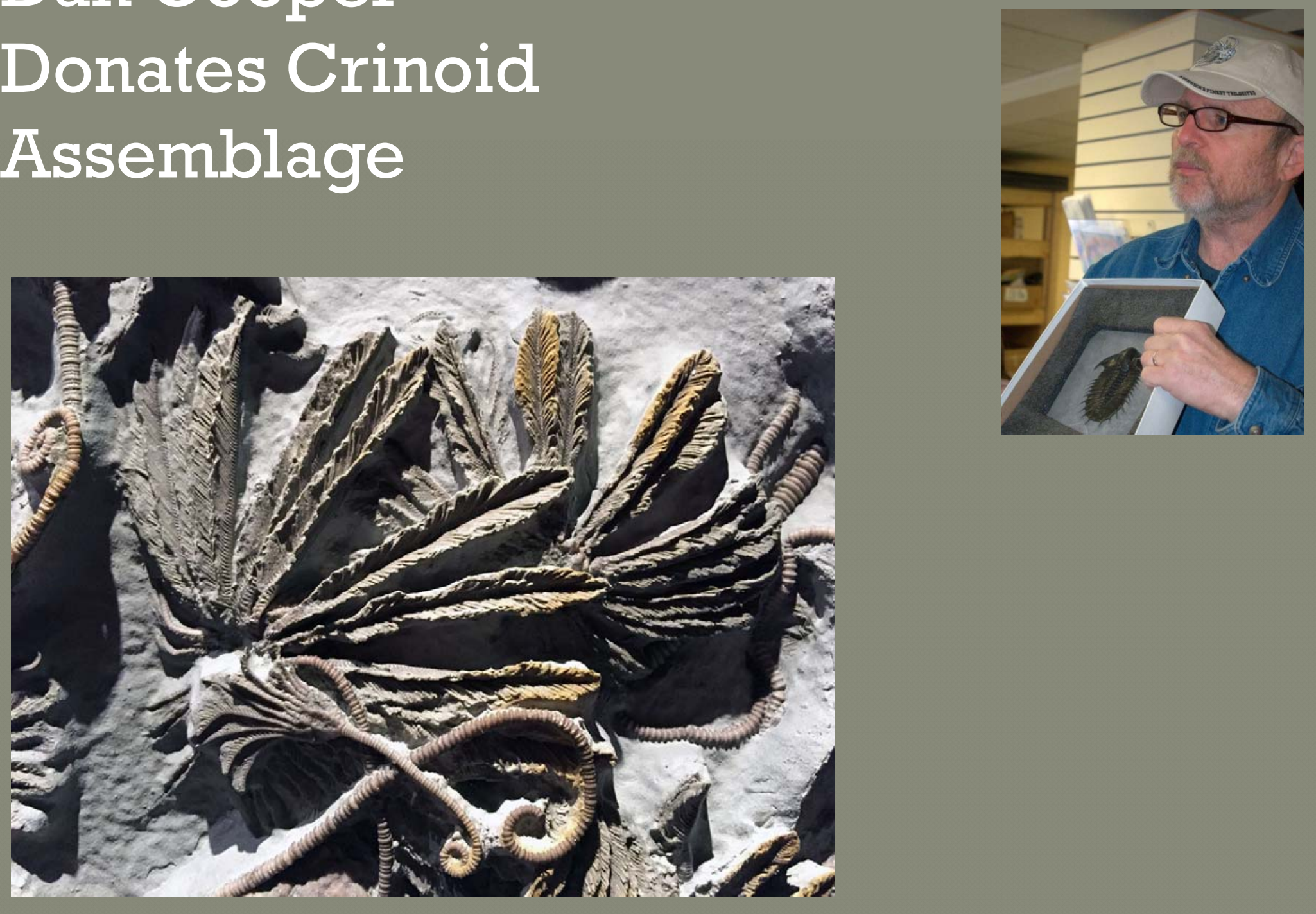


\section{Personal Experiences}

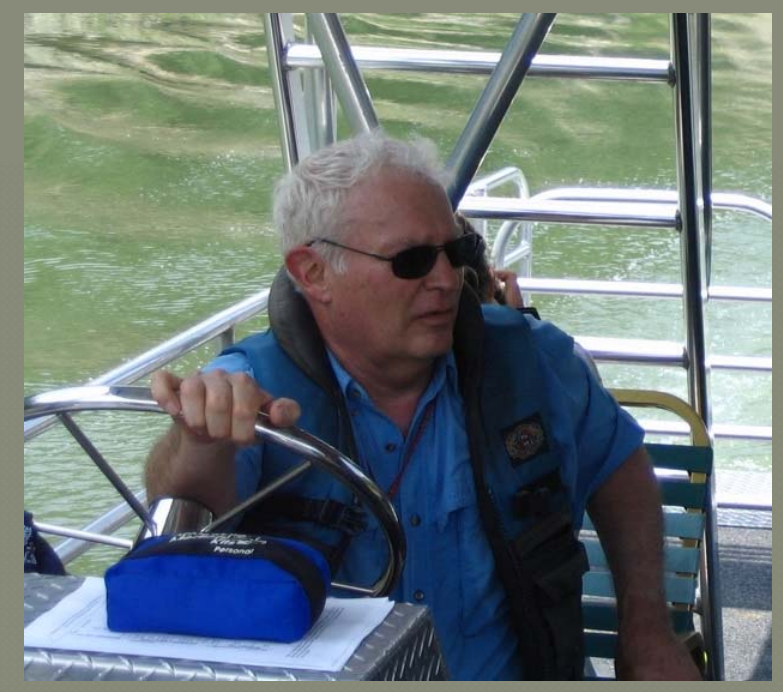

Dave Meyer

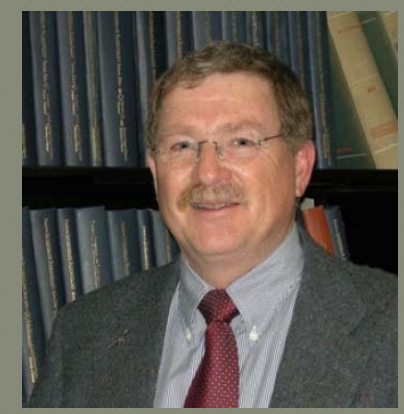

Journal of Paleontology 2015

Bill Ausich
Geology

Today 1997

GSA

Abstracts

2008

Ben Dattilo

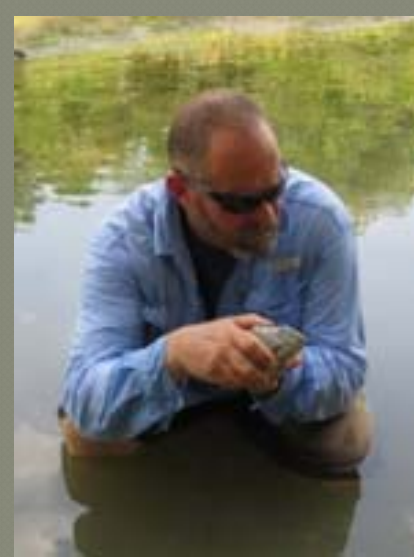

Northeastern Geology 1998

Lethaia 1995
Stephen Donovan

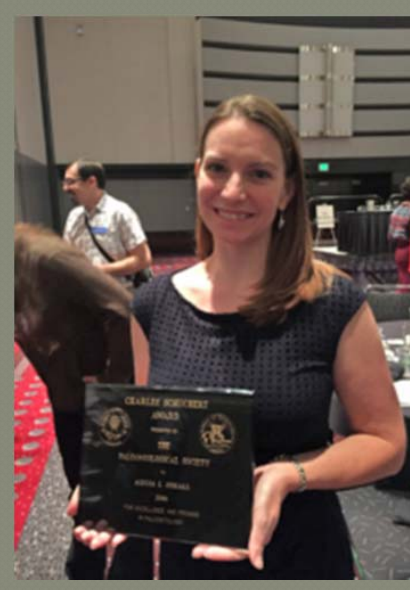

Alycia Stigall
Digital Atlas of

Ordovician Life

Palaios 2016 


\section{Dry Dredgers Philanthropy}

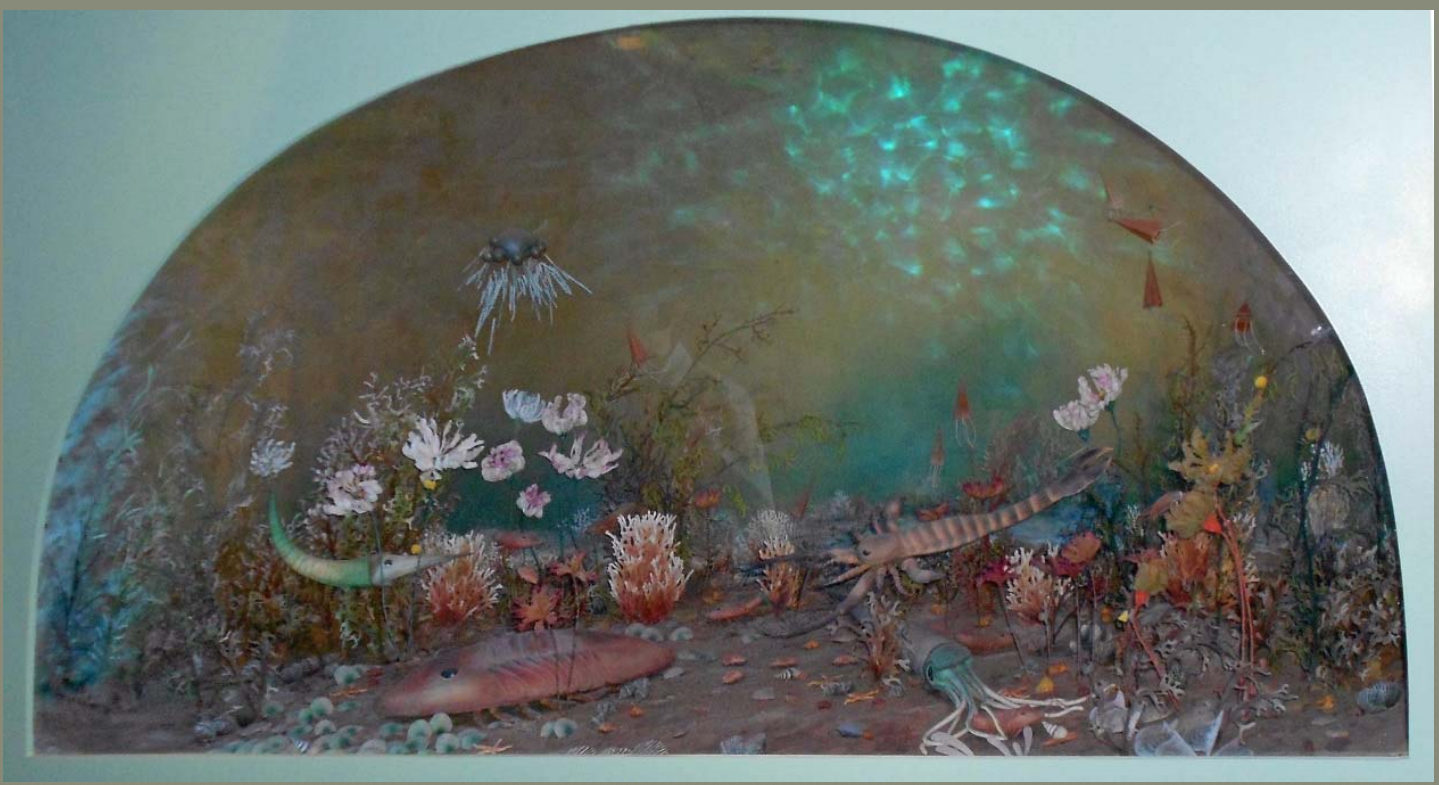

Marschand Ordovician Diorama

- Annual $\$ 500$ donations to U.C. Caster Fund for graduate field work

- 1998 Established the Dry Dredgers Paleontological Research Award - Endowed Fund since 2015

- Funding of various CMC projects 


\section{Amateur Groups Cultivate Future Paleontologists}
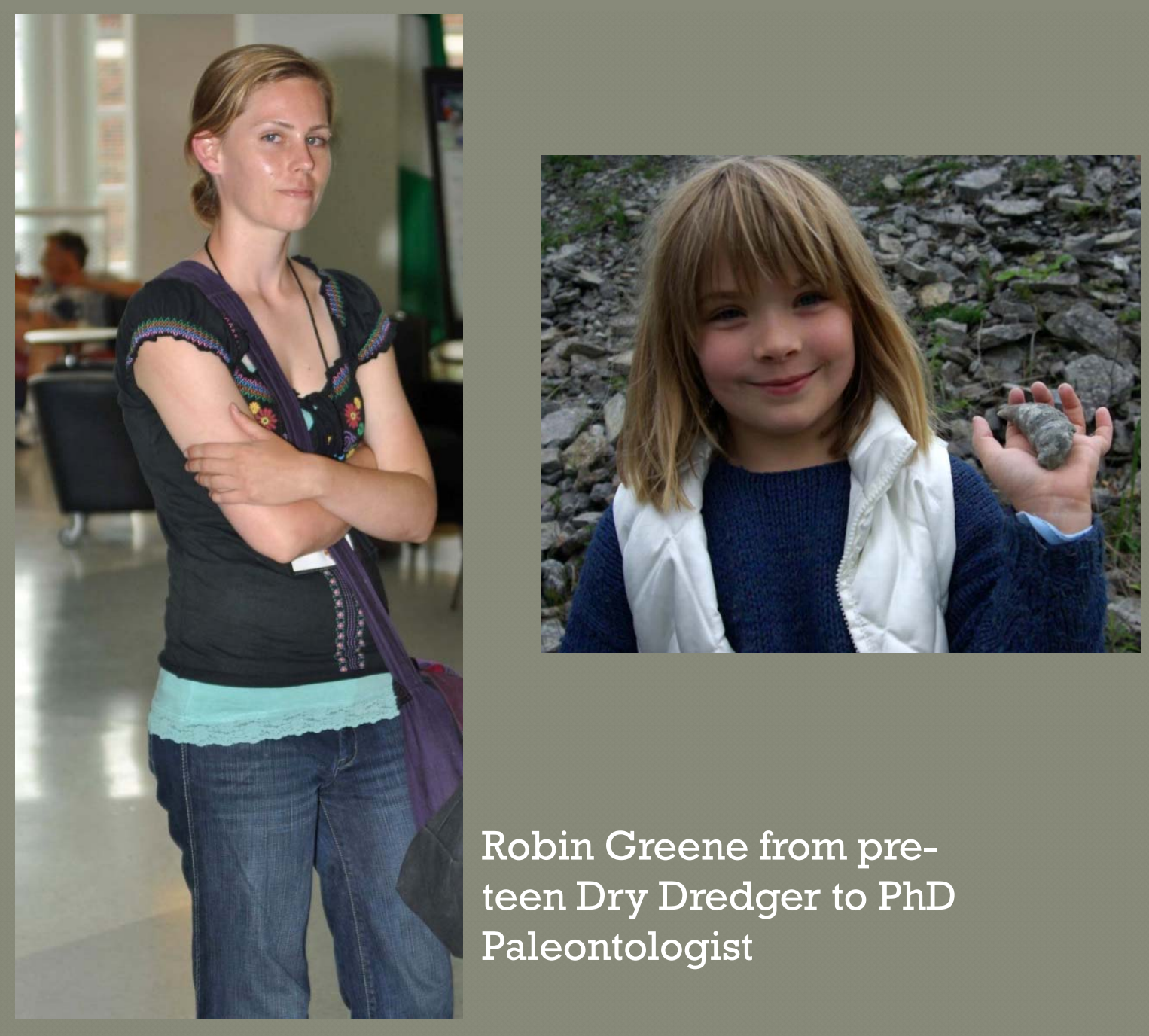

Robin Greene from preteen Dry Dredger to $\mathrm{PhD}$ Paleontologist

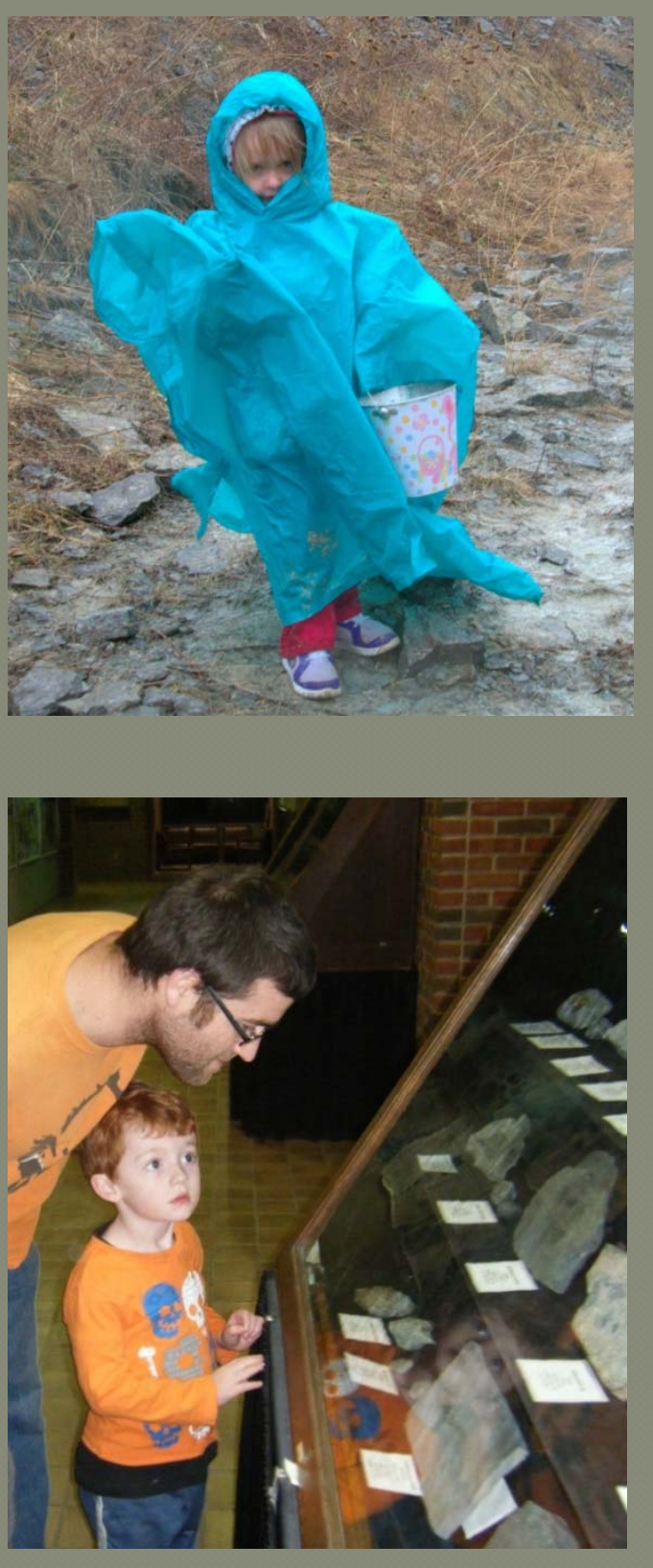




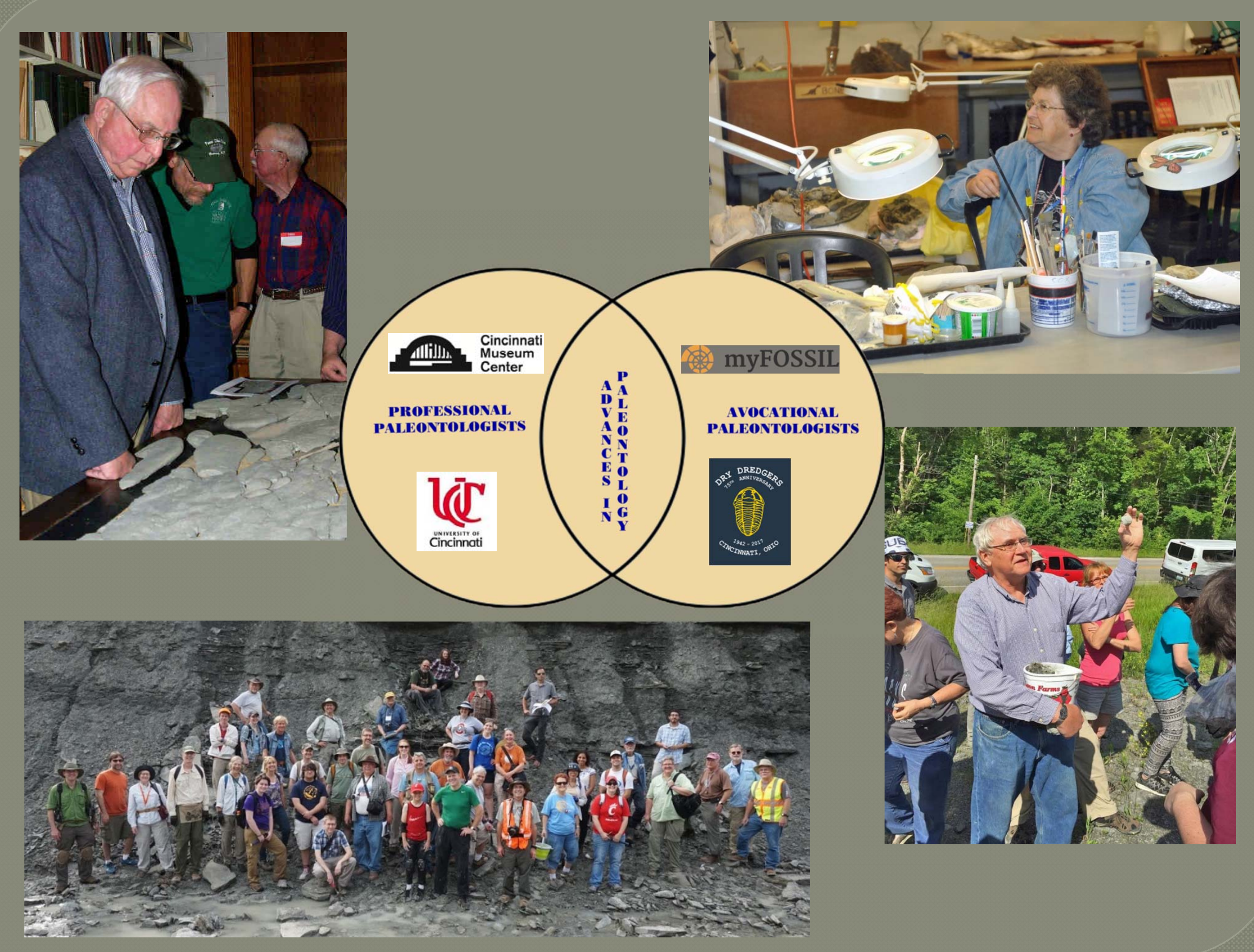




\section{Amateur/Professional Collaboration Advances Paleontological Research}

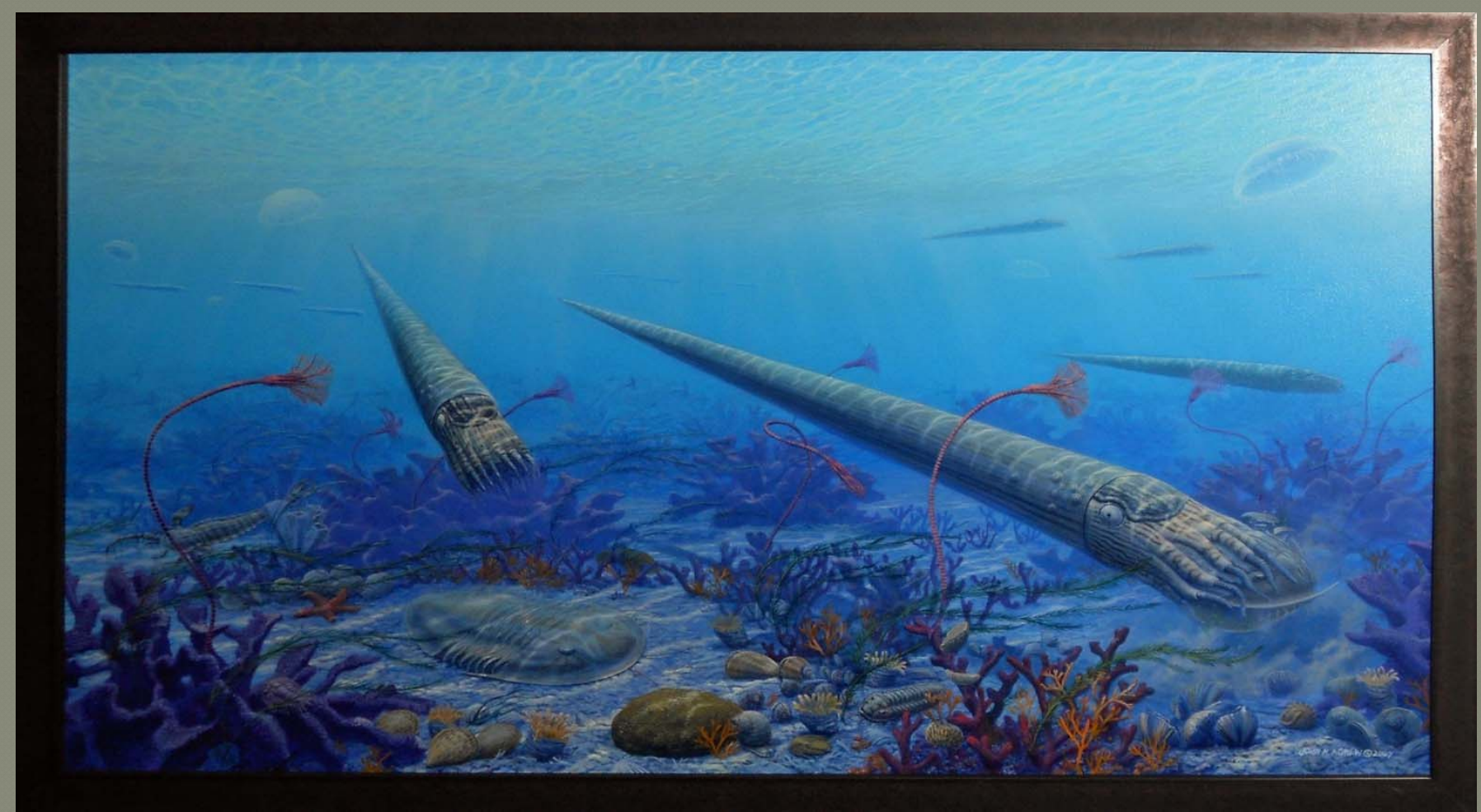

Original cover art for Sea Without Fish by John Agnew

Thanks to Kyle Hartshorn For Help with Graphics 